\title{
Influence of Agronomic Practices on Grassland of Agrostis capillaris L. Festuca rubra L. from „Dealul Crucii" Meadow
}

\author{
Zorica VOŞGAN ${ }^{1 *}$, Roxana VIDICAN ${ }^{2}$, Lucia MIHALESCU ${ }^{1}$, Monica MARIAN ${ }^{1}$, Stela JELEA ${ }^{1}$, Anca \\ DUMUȚA ${ }^{1}$, Oana MARE ROSCA ${ }^{1}$, Susana SFECHIŞ² \\ 1) Technical University of Cluj-Napoca, North University Center of Baia Mare, no.76 Victoriei Street, \\ Romania \\ ${ }^{2)}$ University of Agricultural Sciences and Veterinary Medicine, Cluj-Napoca, Romania \\ *Corresponding author: zori_v13@yahoo.com
}

Bulletin USAMV series Agriculture 72(2)/2015

Print ISSN 1843-5246; Electronic ISSN 1843-5386

DOI 10.15835/buasvmcn-agr: 11392

\begin{abstract}
In Maramures County, meadows are used in a traditional system. They are dominate by Agrostis capillaris and Festuca rubra, with a mixed-use (grazing and mowing). The objectif of our paper is to identify and describe species composition and assessment response to agronomic factors of the Agrostis capillaris L. - Festuca rubra $\mathrm{L}$. grassland type, from „Dealul Crucii” meadow. The grassland of Agrostis capillaris L. - Festuca rubra L. has a floristic composition comprised of Poaceae (45.85\%), Cyperaceae and Juncaceae have a small presence and Fabaceae, valuable species in terms of fodder, have a percentage of 3.37\%. Species from other botanical families occurred in a proportion of $41.34 \%$. From constancy point of view, most species are accidental and only three of them are dominant. This type of grassland has a mesophilic, micro-mesothermal, euriionic character. From agronomic point of view, predominate species medium resistant of mowing and in terms of plant resistance to grazing, most of the species are sensitive to grazing environment and medium resistance to stepping. This is due to the improper agricultural practices and lack of pasture improvement works. The bonitation coefficients indicate that this is an medium category type of pasture with a pastoral value of 1.9 points and supports a load of 0.81 to $1.00 \mathrm{LU} / \mathrm{ha}$.
\end{abstract}

Keywords: agronomic factors, ecological response, grazing, plant resistance.

\section{INTRODUCTION}

Natural grasslands have a particular importance in the existence and global balance of the ecosystem (Huygens et al., 2013). In some regions, in order to protect natural areas, they tried to eliminate the traditional grazing activities; this approach has proved to be ineffective according to Verdu et al., (2000), sheep and goats controlled grazing can maintain the ecosystems biodiversity. Grazing activities have been associated to the sustenance of biodiversity in different ecosystems, because by controlling the mutual interaction of two factors - plant and animal - may be obtained good economic resulting feedback. Biodiversity of natural grasslands is highly important in terms of fodder, as it significantly increases the yield.

As the hilly pastures are dominantly covered by Agrostis capillaris and Festuca, they are used as pastures, grasslands and as a mix of them; they are used extensively and sometimes with a medium intensity due to the grassy carpet covered by spontaneous rural species and due to the pedoclimatic conditions (Marusca et al., 2010). In general, extensive meadows and pastures are less 
productive and give crop with a lower net energy content compared to those managed intensively (Metera et al., 2010).

Agricultural practices undertaken on natural meadows in the village Surdesti were held without monitoring the quality of the grassy carpet. For this reason this work has tried to describe the characters of pastures covered by Agrostis capillaris L. and Festuca rubra L. we shall describe the species, tracking their behaviour due to ecological factors, namely their classification in terms of their response to the agronomic factors.

Our analysis made obvious the way the agricultural practices undertaken over time, without regard to any rule, influenced the evolution of vegetation and on this basis we recommend measures to be taken to improve pasture management.

\section{MATERIALS AND METHODS}

The study conducted and presented in this paper is based on observations and analyzes conducted during 2012 - 2014, on the pasture of Surdesti village (known under the local name "Dealul Crucii"), Maramures County (Fig.1). This meadow is being used in a mixed way and it is located 700 meters high.

The floristic composition was studied with Bran-Blanquet method, by making phytosociological relevés (samples surface). Phyto-sociologic indexes mean abundance-

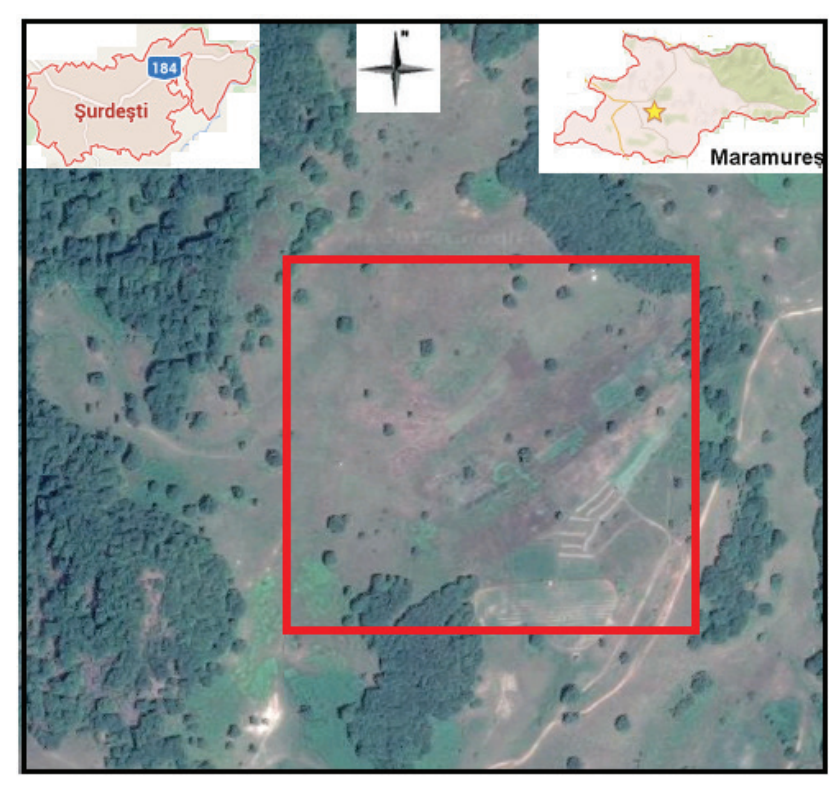

Fig. 1. Satellite image of the experience (http:// maps.google.com, june 2014) dominance (ADm) and constancy $(\mathrm{K})$ have been calculated using the statistics -mathematics method (Cristea et al., 2004).

The species were analized in terms of ecological indicators related to soil moisture, temperature and soil reaction according to the speciality bibliography. Plant resistance to mowing, grazing and stepping were embodied through indicator values (fom 1 to 9 ) by Dierschke and Briemle (2002).

\section{RESULTS AND DISCUSSIONS}

In the hills areas, the pastures and the meadows are specific elements of the landscape; it is the habitat for many species of plants and animals. Agricultural practices undertaken by inhabitants on such lands are mainly grazing and mowing in order to feed animals. In Maramures County, meadows are mostly covered by Agrostis capillaris and Festuca rubra (Barbos, 2006) and the „Dealul Crucii” meadow, Şurdeşti village, the species is found in a significant proportion.

The grassland of Agrostis capillaris L. - Festuca rubra L. has a floristic composition comprised of Poaceae (45.85\%), where the Agrostis capillaris L. species is noticed with $18 \%$ and Festuca rubra L. is present at a rate of $15.93 \%$. Besides these dominantspecies of Poaceae, there are the indicator species as follows Anthoxanthum odoratum L., Festuca pratensis Huds, Cynosurus cristatus L. and accesory species as Dactylis glomerata L., Briza media L. Species from Cyperaceae and Juncaceae have avery reduced cover, with a ADm of $0.5 \%$. Representatives of these botanical families Carex pullescens, Juncus effuses, Luzula campestris, are considered accidental species, given that the land has a slope of $5-10 \%$ and thin soil water retention is not achieved (Bogdan et al., 2011). The Fabaceae are most valuable in terms of fodder are present in a proportion of $3.37 \%$, and the dominant species are Lotus corniculatus L. Plants from other botanical families are present with a ADm of $41,34 \%$, of which with significant presence are Centaurea phrygia L., Achillea millefolium L., Pteridium aquilinum L., Thymus serpyllum L. There are also species such as Urtica dioica L. and Rumex crispus L. which indicate a longer beyond the limit stay of the animals on the same spot during pasturing time (Tab. 1).

To highlight the degree of fidelity of the species in the meadow covered by Agrostis capillaris 
- Festuca rubra we have calculated individuals constancy in the sample areas analyzed; thus it was found that 17 species are accidental, 9 species are accompanying ones, 8 are indicator species, 4 species are frequent, 3 species are dominant (Fig.2). There is a decrease in the number of species from the lower frequency classes to the higher classes. The trend is easily predictable and obvious, given the conditions when the biotop's limited resources maintain the abundance of most of the species at a relatively low level in behalf of dominant speciesand good competitors (Rotar et al., 2014).

Regarding the agronomic value of grasslands, indicate that this is an medium category type of pasture with a pastoral value of 1.9 points and supports a load of 0.81 to $1.00 \mathrm{LU} / \mathrm{ha}$.

Regarding the ecological response of plant species growing on the lawn of the "Dealul Crucii", we have found that the following species: mesophilic, micromezoterme and the euriionic ones are predominant, according to the climatic conditions of the area of research.

Tab. 1. Species composition and assessment of the Agrostis capillaris - Festuca rubra grassland type

\begin{tabular}{|c|c|c|c|c|c|c|c|c|}
\hline \multirow[t]{2}{*}{ Floristic composition } & \multicolumn{3}{|c|}{ Ecological indexes } & \multicolumn{3}{|c|}{$\begin{array}{l}\text { Agronomical } \\
\text { indexes }\end{array}$} & \multirow[t]{2}{*}{$\mathrm{ADm}$} & \multirow[t]{2}{*}{$\mathrm{K}$} \\
\hline & $\mathrm{U}$ & $\mathrm{T}$ & $\mathrm{R}$ & MR & GR & STR & & \\
\hline Poaceae & & & & & & & 45.85 & \\
\hline Agrostis capillaris & $\mathrm{x}$ & $\mathrm{x}$ & 4 & 6 & 5 & 5 & 18 & 5 \\
\hline Anthoxanthum odoratum & $\mathrm{x}$ & $\mathrm{x}$ & 5 & 7 & 5 & 5 & 4.25 & 4 \\
\hline Briza media & $\mathrm{x}$ & $\mathrm{x}$ & $\mathrm{x}$ & 4 & 4 & 4 & 0.12 & 1 \\
\hline Cynosurus cristatus & 3 & 3 & 3 & 7 & 7 & 7 & 1.81 & 3 \\
\hline Dactylis glomerata & 5 & $\mathrm{x}$ & $\mathrm{x}$ & 8 & 4 & 6 & 0.67 & 2 \\
\hline Festuca pratensis & 6 & $\mathrm{x}$ & $\mathrm{x}$ & 6 & 4 & 6 & 5.07 & 3 \\
\hline Festuca rubra & 5 & $\mathrm{x}$ & $\mathrm{x}$ & 9 & 7 & 6 & 15.93 & 5 \\
\hline Cyperaceae/Juncaceae & & & & & & & 0.5 & \\
\hline Carex pullescens & $\mathrm{x}$ & 4 & 4 & 4 & 5 & 5 & 0.25 & 1 \\
\hline Juncus effusus & 7 & 5 & 4 & 4 & 7 & 6 & 0.12 & 1 \\
\hline Luzula campestris & 4 & $\mathrm{x}$ & 3 & 5 & 5 & 5 & 0.12 & 1 \\
\hline Fabaceae & & & & & & & 3.37 & \\
\hline Lotus corniculatus & 4 & $\mathrm{x}$ & 7 & 6 & 4 & 4 & 2.25 & 4 \\
\hline Trifolium repens & 5 & $\mathrm{x}$ & 6 & 8 & 8 & 8 & 0.75 & 2 \\
\hline Trifolium pratense & $\mathrm{x}$ & $\mathrm{x}$ & $\mathrm{x}$ & 7 & 4 & 4 & 0.12 & 1 \\
\hline Medicago lupulina & 2.5 & 3 & 4 & 6 & 4 & 5 & 0.25 & 2 \\
\hline Species from other botanical families & & & & & & & 41.34 & \\
\hline Achillea millefolium & 4 & $\mathrm{x}$ & $\mathrm{x}$ & 7 & 4 & 5 & 3.75 & 5 \\
\hline Campanula patula & 5 & 6 & 7 & 5 & 2 & 2 & 0.81 & 3 \\
\hline Centaurea phrygia & 5 & 4 & 5 & 5 & 2 & 2 & 3.97 & 4 \\
\hline Chrysanthemum leucanthemum & 4 & $\mathrm{x}$ & $\mathrm{x}$ & 6 & 3 & 4 & 2.60 & 3 \\
\hline Cirsium vulgare & 5 & 5 & 8 & - & - & - & 0.12 & 1 \\
\hline Fragaria vesca & 5 & $\mathrm{x}$ & $\mathrm{x}$ & - & - & - & 0.12 & 1 \\
\hline Galium aparine & 4 & 5 & 5 & 4 & 4 & 4 & 0.18 & 1 \\
\hline Galium mollugo & 4 & 6 & 7 & 5 & 4 & 4 & 1.67 & 2 \\
\hline Hypericum maculatum & 6 & $\mathrm{x}$ & 3 & 3 & 3 & 3 & 2.85 & 3 \\
\hline Pimpinella saxifraga & 2 & $\mathrm{x}$ & 3 & 5 & 3 & 2 & 2.25 & 1 \\
\hline Plantago lanceolata & $\mathrm{x}$ & $\mathrm{x}$ & $\mathrm{x}$ & 7 & 6 & 6 & 2.31 & 3 \\
\hline Polygala vulgaris & 5 & $\mathrm{x}$ & 3 & 4 & 4 & 4 & 1.25 & 2 \\
\hline
\end{tabular}


Tab. 1. Species composition and assessment of the Agrostis capillaris - Festuca rubra grassland type - continued

\begin{tabular}{|c|c|c|c|c|c|c|c|c|}
\hline \multirow[t]{2}{*}{ Floristic composition } & \multicolumn{3}{|c|}{ Ecological indexes } & \multicolumn{3}{|c|}{$\begin{array}{l}\text { Agronomical } \\
\text { indexes }\end{array}$} & \multirow[t]{2}{*}{$\mathrm{ADm}$} & \multirow[t]{2}{*}{$\mathrm{K}$} \\
\hline & $\mathrm{U}$ & $\mathrm{T}$ & $\mathrm{R}$ & MR & GR & STR & & \\
\hline Species from other botanical families & & & & & & & 41.34 & \\
\hline Potentilla erecta & $\mathrm{x}$ & $\mathrm{x}$ & $\mathrm{x}$ & 8 & 4 & 5 & 0,25 & 1 \\
\hline Pteridium aquilinum & $\mathrm{x}$ & $\mathrm{x}$ & $\mathrm{x}$ & 8 & 6 & 6 & 3,65 & 2 \\
\hline Ranunculus auricomus & $\mathrm{x}$ & $\mathrm{x}$ & $\mathrm{x}$ & 2 & 2 & 3 & 1,87 & 2 \\
\hline Rhinanthus minor & $\mathrm{x}$ & 5 & $\mathrm{x}$ & 5 & 8 & 3 & 2,25 & 4 \\
\hline Rumex acetosa & $\mathrm{x}$ & $\mathrm{x}$ & $\mathrm{x}$ & 6 & 4 & 2 & 1,12 & 1 \\
\hline Rumex acetosela & 2 & 3 & 2 & 6 & 4 & 2 & 0,67 & 1 \\
\hline Rumex crispus & 4 & $\mathrm{x}$ & $\mathrm{x}$ & 7 & 7 & 7 & 2,25 & 2 \\
\hline Scabiosa ochroleuca & 3 & 5 & 6 & 5 & 3 & 4 & 0,12 & 1 \\
\hline Stellaria graminea & 4 & $\mathrm{x}$ & 4 & 4 & 5 & 5 & 0,45 & 2 \\
\hline Taraxacum officinale & 5 & $\mathrm{x}$ & $\mathrm{x}$ & 8 & 7 & 7 & 1,81 & 3 \\
\hline Thymus serpyllum & 4 & $\mathrm{x}$ & $\mathrm{x}$ & 4 & 4 & 4 & 3,11 & 3 \\
\hline Urtica dioica & $\mathrm{x}$ & $\mathrm{x}$ & $\mathrm{x}$ & 5 & 4 & 4 & 0,67 & 1 \\
\hline Vaccinium myrtillus & 5 & $\mathrm{x}$ & $\mathrm{x}$ & 2 & 3 & 2 & 0,12 & 1 \\
\hline Veronica chamaedrys & 5 & $\mathrm{x}$ & $\mathrm{x}$ & 7 & 6 & 6 & 0,87 & 1 \\
\hline Viola arvensis & 4 & $\mathrm{x}$ & 3 & 4 & 2 & 2 & 0,25 & 1 \\
\hline
\end{tabular}

U-humidity, T-temperature, R-soil reaction, MR-Resistant to mowing, GR-Resistant to grazing, SRT-Resistant to stepping, ADm $=$ mean abundance-dominance, $\mathrm{K}$ = constancy.

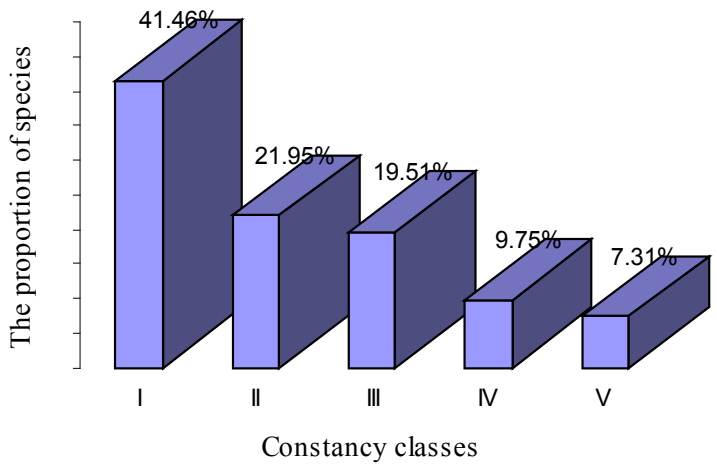

Fig. 2. Distribution on constancy classes of Agrostis capillaris L. - Festuca rubra L.

Given that each year the meadow is subject to agronomic works, such as mowing and grazing, we have examined the plant resistance mowing, resistance to grazing and resistance to stepping. Regarding plant resistance to mowing, we found that 15 species are medium resistant, 12 resistant, 9 are medium sensitive, 2 species susceptible and 1 extremely resistant. The study of the grazing resistant species of plants, demonstrated that 20 species are medium sensitive to grazing environment, 9 species are medium resistant,
6 species are resistant to grazing, 4 species are sensitive to grazing. Regarding resistance to stepping, noted a number of 15 species medium resistance, 13 species medium sensitive to stepping, 7 species susceptible and 4 species resistant. The largest coverage on grassland of Agrostis capillaris L. - Festuca rubra L. from „Dealul Crucii" meadow have species resistant to mowing, being used in an extensive to medium intensive system, grazing sensitive environmental species, which denote the environment sensitive to pasture grazing and medium resistance to stepping.

\section{CONCLUSION}

Our analysis of the "Dealul Crucii" vegetationSurdesti village has identified a meadow mainly covered by Agrostis capillaris L. - Festuca rubra L. with an average agronomic value following an extensive management. From the point of the ecological indices, this type of meadow is mesophilic, micro mezotherme and euriionic.

The influence of agronomic works on the grassy carpet indicates a decrease in species resistant to grazing, and those medium sensitive are predominant. The plant species medium 
resistant to mowing and medium resistance to stepping are more frequent.

Thus, it must be given a greater attention to the methods of the land use and to the methods meant to improve the meadow output in order to obtain favourable results.

\section{REFERENCES}

1. Bărbos MI (2006). Montane grasslands dominated by Agrostis capillaris and Festuca rubra in Maramureș county I. Phytosociological analysis. Contributions Botanical. Botanical Garden "Alexandru Borza" Cluj-Napoca 41(2):41-52.

2. Bogdan A, Rotar I, Pacurar F, Vidican R, Dale L (2011). Study of the ecosystem of Arnica montana L. from Bear Meadows. Bulletin UASVM Agriculture 68(1):58-61.

3. Cristea V, Gafta D, Pedrotti F (2004). Phytosociology. University Press Cluj-Napoca.

4. Dierschke H. Briemle G. (2002). Kulturgrasland. Wiesen, Weiden und verwandte Staudenlluren. Ed. Verlag Eugen Ulmer GmbH \& Co. Stuttgart Germania 31-33, 205-216.
5. Huygens D, Rotar I, Vidican R, Pacurar F, Carlier L, Mălinas A (2013). The influence of different type of management upon the floristic structure of grasslands systems, with special attention on Arnica montana L. Bulletin UASMV series Agriculture 70(1):30-35.

6. Marușca T, Mocanu V, Cardașol V, Hermenean I, Blaj VA, Oprea G, Tod MA (2010). Guide organic production of mountain meadows feed. Transilvania University Brasov.

7. Metera E, Sakowski T, Słoniewski K, Romanowicz B (2010). Grazing as a tool to maintain biodiversity of grassland - a review. Animal Science Papers and Reports 28 (4):315-334.

8. Rotar I, Pacurar F, Pleșa A, Vidican R, Nagy M. (2014). Ecologic and agronomic aspects of Agrostis Capillaris L. - Trisetum Flavescens (L.) P. Beauv. grassland subtype. Bulletin USAMV series Agriculture 71(2):295-301.

9. Verdù JR, Crespo MB, Galante E (2000). Conservation strategy of a nature reserve in Mediterranean ecosystems: The effects of protection from grazing on biodiversity. In: Biodiversity and Conservation 9:1707-1721. 